\title{
The first study of molecular prevalence and species characterization of Cryptosporidium in free-range chicken (Gallus gallus domesticus) from Brazil
}

Primeiro estudo de prevalência molecular e caracterização de espécies de Cryptosporidium em galinhas (Gallus gallus domesticus) colonial/caipiras do Brasil

Maria Paula de Carvalho Ewald ${ }^{1}$; Felippe Danyel Cardoso Martins ${ }^{1}$; Eloiza Teles Caldart ${ }^{1}$;

Fernando Emmanuel Gonçalves Vieira²; Milton Hissashi Yamamura' ${ }^{1}$; João Pedro Sasse' ${ }^{1}$ Luiz Daniel de Barros ${ }^{1}$; Roberta Lemos Freire'; Italmar Teodorico Navarro ${ }^{1}$; João Luis Garcia ${ }^{1 *}$

\author{
${ }^{1}$ Laboratório de Protozoologia, Departamento de Medicina Veterinária Preventiva, Universidade Estadual de Londrina - UEL, \\ Londrina, PR, Brasil \\ ${ }^{2}$ Laboratório de Parasitologia, Centro de Ciências Humanas e da Educaçāo, Universidade Estadual do Norte do Paraná - UENP, \\ Jacarezinho, PR, Brasil
}

Received September 1, 2017

Accepted October 31, 2017

\begin{abstract}
Rearing free-range chicken is based on grazing feeding patterns, and these animals could be potential environmental contaminants of Cryptosporidium oocysts for humans and other animals. Therefore, the present study aimed to evaluate the molecular prevalence of Cryptosporidium spp. in free-range chickens from Brazil. A total of 351 fecal samples from chickens were examined from 20 farms. For detection of Cryptosporidium spp., $18 \mathrm{~S}$ rRNA gene fragments were amplified using a nested PCR reaction. Positive samples were sent for sequencing. The overall prevalence of Cryptosporidium was $25.6 \%(95 \% \mathrm{CI}=21.2 \%-30.6 \%)$. Sequencing of the amplified fragments allowed for the identification of three species: C. meleagridis in 57 (62.6\%), C. baileyi in 15 (16.4\%), C. parvum in $3(3.2 \%)$ samples, and a new Cryptosporidium genotype ( $C$. genotype BrPR1) in $3(3.2 \%)$ samples. Cryptosporidium genotype BrPR1 has not yet been classified as a species, and its host spectrum is not known. Cryptosporidium, including zoonotic species, exists at a high prevalence in free-range chickens within the region studied.
\end{abstract}

Keywords: Cryptosporidiosis, zoonosis, public health, epidemiology.

\section{Resumo}

A criação de galinhas no estilo colonial/caipira é baseada em padrões de alimentação de pastagem, o que as torna potenciais contaminantes ambientais de oocistos de Cryptosporidium para humanos e outros animais. Portanto, o presente estudo teve como objetivo avaliar a prevalência molecular de Cryptosporidium spp. em galinhas criadas em sistema colonial/caipira. Um total de 351 amostras de fezes de frangos foram examinadas em 20 fazendas. Para a detecçáo de Cryptosporidium spp., os fragmentos do gene rRNA $18 \mathrm{~S}$ foram amplificados utilizando-se a reação de nested-PCR. A prevalência global de Cryposporidium foi de 25,6\% (IC 95\% = 21,2\% - 30,6\%). O sequenciamento dos fragmentos amplificados permitiu a identificação de três espécies que infectam aves: C. meleagridis em 57 (62,6\%), C. baileyi em 15 (16,4\%), C. parvum em 3 (3,2\%) amostras, bem como, um novo genótipo de Cryptosporidium (C. genótipo BrPR1) foi identificado em $3(3,2 \%)$ amostras. Cryptosporidium genotipo BrPR1 não foi ainda classificado como uma espécie, e seu espectro de hospedeiros é desconhecido. O presente trabalho permitiu concluir que Cryptosporidium, incluindo espécies zoonóticas, existe com alta prevalência em galinhas criadas em sistema colonial/caipira na regiáo estudada.

Palavras-chave: Criptosporidose, zoonoses, saúde pública, epidemiologia.

\footnotetext{
*Corresponding author: João Luis Garcia. Laboratório de Protozoologia, Departamento de Medicina Veterinária Preventiva, Universidade Estadual de Londrina - UEL, Rodovia Celso Garcia Cid, Km 380, CEP 86057-970, Londrina, PR, Brasil. e-mail: joaoluisgarcia10@gmail.com
} 


\section{Introduction}

Cryptosporidium can infect a wide variety of vertebrate animals, including mammals, birds, amphibians, reptiles, and fish (RYAN \& HIJJAWI, 2015). Three species of Cryptosporidium have been identified in chickens: C. meleagridis, C. baileyi, and C. galli (CURRENT et al., 1986; PAVLÁSEK, 2001; SLAVIN, 1955). Of these three, $C$. meleagridis has zoonotic potential and causes watery diarrhea, abdominal pain, nausea, vomiting, and fever in humans (CHAPPELL et al., 2011; CHAPPELL et al., 2015). Additionally, in some studies of HIV-patients, the prevalence of C. meleagridis is similar to that of C. parvum (GATEI et al., 2003; CAMA et al., 2007).

Cryptosporidiosis can be acquired through several routes, including person-to-person contact, ingestion of contaminated food, drinking, and recreational water, as well as contact with companion and farm animals (GRIFFITHS, 1998; MAcKENZIE et al., 1994; SHIELDS et al., 2008; SMITH et al., 2007; TANGERMANN et al., 1991). Therefore, because the production of free-range chickens is based on grazing feeding patterns, these animals are potential biological vectors for the environmental contamination of oocysts (THAMSBORG et al., 1999).

In considering the demands of consumers in industrialized nations who desire meat raised without chemical agents in welfare-friendly and organic systems, there is an association with the popular concept that animals raised under free-range conditions are sanitary and safer than those reared indoors (WANG et al., 2009). However, considering host-pathogen interactions, outdoor animals may have inherently more risk to be infected with zoonotic parasites or act as infection sources for several animals and humans (THAMSBORG et al., 1999). Despite this perception, there is no study focusing on characterizing Cryptosporidium spp. from free-range chicken production systems.

Therefore, the present study is aimed at evaluating the molecular prevalence of Cryptosporidium spp. in chickens raised under free-range systems in southern Brazil.

\section{Materials and Methods}

\section{Study population and sampling}

Fecal samples from 351 free-range chickens, aged between 90 and 190 days, were collected between August 2011 to February 2014. Samples were acquired from 20 farms located in 10 different cities from the northern Parana state, southern Brazil. All animals were raised in free-range system and slaughtered at farms for human consumption. Conglomerate sampling was carried out proportional to the number of animals slaughtered in the period. The sample size was calculated assuming a prevalence of $35 \%$ (BAROUDI et al., 2013) with a confidence level of $95 \%$ and efficacy of $5 \%$ by Epi Info 3.5.4. A questionnaire including several factors, such as, presence of other animals, water source, presence of fence, and population density, was applied to all farmers to determine possible risk association.

Fecal samples were collected from the distal portion of the rectum and stored at $-20{ }^{\circ} \mathrm{C}$ until DNA extraction. This study was approved by Ethics Committee of the Universidade Estadual de Londrina (Protocol n 206/12).

\section{DNA extraction and nested-PCR}

DNA extraction was performed using the NucleoSpin ${ }^{\circledR}$ Tissue Kit (Macherey-Nagel, Düren, Germany) according to the manufacturer's instructions. For detection of Cryptosporidium spp., $18 \mathrm{~S}$ rRNA gene fragments were amplified using a nested PCR (n-PCR) reaction using primers previously described by (XIAO et al., 1999). The first PCR reaction consisted of $9.25 \mu \mathrm{L}$ of autoclaved ultrapure water, $2.5 \mu \mathrm{L}$ of buffer $10 \mathrm{X}$ concentrate, $0.5 \mu \mathrm{L}$ dNTP $(10 \mathrm{mM}), 1.25 \mu \mathrm{L} \mathrm{MgCl}_{2}(50 \mathrm{mM}), 0.5 \mu \mathrm{L}$ of each primer $20 \mathrm{pmol} / \mathrm{uL}$ (forward and reverse), Platinum ${ }^{\mathrm{Tm}} \mathrm{Taq}$ DNA Polymerase (Invitrogen ${ }^{\mathrm{TM}}$, Carlsbad, CA, USA) $0.25 \mu \mathrm{L}(5 \mathrm{U} / \mu \mathrm{L})$, and $2.0 \mu \mathrm{L}$ of genomic DNA, reaching a final volume of $25 \mu \mathrm{L}$. To reduce unused primers from the primary PCR, the first round of PCR products was diluted 1:5 with $\mathrm{dH}_{2} \mathrm{O}$. The conditions for each second-round reaction were identical to the first. Initial heating was carried out at $95^{\circ} \mathrm{C}$ for 5 minutes followed by 35 cycles, each cycle consisting of $94^{\circ} \mathrm{C}$ for 45 seconds (denaturation), $55^{\circ} \mathrm{C}$ for 45 seconds (annealing) and $72{ }^{\circ} \mathrm{C}$ for 60 seconds (extension). One final extension step at $72{ }^{\circ} \mathrm{C}$ for 5 minutes was included. The PCR products were subjected to electrophoresis on $1.5 \%$ agarose gel (Ultrapure ${ }^{\mathrm{TM}}$ Agarose, Invitrogen ${ }^{\mathrm{TM}}$, Carlsbad, CA, USA) stained with SYBR ${ }^{\circledR}$ Safe (Invitrogen, Carlsbad, CA, USA), visualized by ultraviolet light and photodocumented using program LPix Image ST (Loccus Biotecnologia, Cotia, SP, Brazil). Negative and positive controls consisting of ultrapure water and $C$. muris DNA respectively, were included in each batch.

\section{Sequence analysis of SSU rRNA gene}

The positive PCR products were purified from agarose gel using a PureLink ${ }^{\mathrm{TM}}$ Quick Gel Extraction Kit (Invitrogen ${ }^{\mathrm{TM}}$, Carlsbad, CA, USA) and quantified using a Picodrop ${ }^{\mathrm{TM}}$ Spectrophotometer (Invitrogen $^{\text {Tw }}$, Carlsbad, CA, USA). The sequencing was performed using the BigDye Terminator ${ }^{\mathrm{TM}}$ v.3.1 Cycle Sequencing kit (Applied Biosystems, Carlsbad, USA) with second reaction forward and reverse primers using a 3500 Genetic Analyzer (Applied Biosystems ${ }^{\mathrm{TM}}$, Carlsbad, USA) according to the manufacturer's instructions. The obtained sequences were analyzed in Chromas Lite v.2.6.1, and the contigs were generated in BioEdit (Biological Sequence Alignment Editor) v.7.2.5 (HALL, 1999). dentity was verified with sequences deposited in the GenBank ${ }^{\Theta}$ using BLAST algorithm (http://blast.ncbi.nlm.nih.gov/Blast.cgi) and by manual alignment using the program BioEdit (Biological Sequence Alignment Editor). Phylogenetics analysis were carried out using neighbor-joining method with bootstrap values derived from 1000 replicates in MEGA v7.0.14, evolutionary distances were calculated by Kimura 2-parameter method. When uncommon Cryptosporidium species were identified on $18 \mathrm{~S}$ n-PCR, we performed n-PCR for actin and $h s p 70$ genes and posterior sequencing at the same conditions as described above for $18 \mathrm{~S}$ rRNA n-PCR (SULAIMAN et al., 2000, 2002). 


\section{Statistical analysis}

Association of the risks between variables and positivity to Cryptosporidium spp. was performed using the chi-square test or Fisher's exact test, and a 5\% significance level was adopted. The measure of association Odds Ratio was calculated with a $95 \%$ confidence interval. The statistical package Epi 3.5.4. (DEAN et al., 2011) was used for analysis.

\section{Results}

$18 \mathrm{~S}$ rRNA n-PCR reactions were positive for Cryptosporidium spp. in $91(25.9 \%)$ of 351 fecal samples (Table 1$)$. The prevalence at the farms ranged from 0 to $80 \%$, and $16(80 \%)$ of them were positive for Cryptosporidium spp.. Those positive samples tested at $18 \mathrm{~S}$ rRNA n-PCR were submitted for sequencing (Table 1 ), and $57(62.6 \%), 15(16.4 \%), 3(3.2 \%)$, and $3(3.2 \%)$ were detected as $C$. meleagridis, $C$. baileyi, and $C$. parvum, and a new genotype named $C$. genotype BrPR1 ( $n=3,3.2 \%)$, respectively. Thirteen samples did not have good amplification results due to low DNA quality. The identities on BLAST were confirmed as 99 to $100 \%$ for C. meleagridis (KT151551.1, EU814432.1) and C. baileyi (GQ426096.1, AF093495.1, KT151550.1, EU814432.1), $100 \%$ for C. parvum (KU892559.1, AF164102.1), and $99 \%$ for C. bovis (KT922231.1). Phylogenetically, three from the $18 \mathrm{~S}$ rRNA n-PCR (Figure 1) showed three clusters that were very well defined. Three isolates CryBrFRChi98/104/106 clustered with C. parvum, CryBrFRChi 24/plus 54 isolates clustered

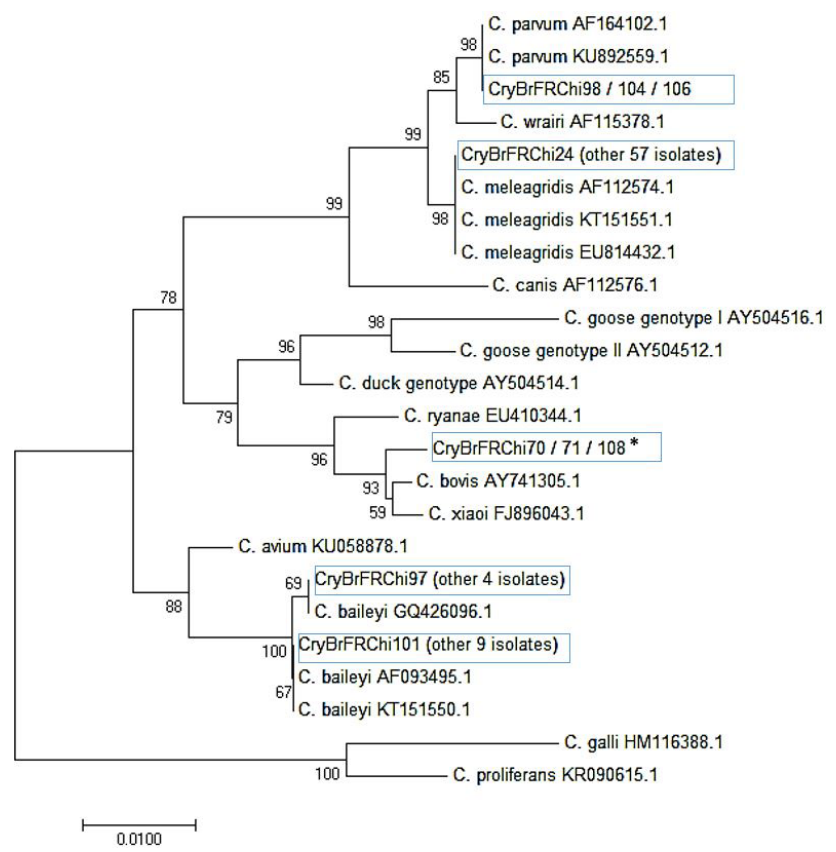

Figure 1. Phylogenetic relationships between Cryptosporidium spp. found in this study by $18 \mathrm{~S}$ rRNA and selected Cryptosporidium spp. from GenBank inferred by Neighbor-joining (ML). The percentage of replicate trees in which the associated taxa clustered together in the bootstrap test (1000 replicates) are shown next to the branches. Cryptosporidium galli and C. proliferans were used as outgroup. Isolates obtained in the present study were marked as CryBrFRCh\# (Cryptosporidium Brazil Free Range Chickens and the number of respective sample). ${ }^{*}$ New genotype (Cryptosporidium genotype BrPR1).

Table 1. Results of positivity in $18 \mathrm{~S}$ rRNA nested-PCR for Cryptosporidium from fecal samples in free-range chickens from the northern Paraná state, Brazil.

\begin{tabular}{|c|c|c|c|c|c|c|c|c|}
\hline \multirow{2}{*}{ Farms } & \multirow{2}{*}{ Cities } & \multirow{2}{*}{$\mathbf{n}$} & \multirow{2}{*}{$\begin{array}{c}\text { n-PCR } \\
+/ \%\end{array}$} & \multicolumn{5}{|c|}{ Sequencing result } \\
\hline & & & & C. meleagridis & C. baileyi & C. parvum & C. bovis & NAQ* $^{*}$ \\
\hline 1 & A & 70 & $10 / 14.3$ & 9 & & & & 1 \\
\hline 2 & & 15 & $5 / 33.3$ & 4 & & & & 1 \\
\hline 3 & $\mathrm{~B}$ & 5 & $4 / 80$ & & 2 & & & 2 \\
\hline 4 & & 59 & $29 / 49.1$ & 23 & 2 & 2 & & 2 \\
\hline 5 & $\mathrm{C}$ & 8 & $0 / 0$ & & & & & \\
\hline 6 & $\mathrm{D}$ & 10 & $2 / 20$ & 1 & 1 & & & \\
\hline 7 & $\mathrm{E}$ & 35 & $2 / 5.7$ & 1 & 1 & & & \\
\hline 8 & & 5 & $1 / 20$ & & & & & 1 \\
\hline 9 & & 6 & $0 / 0$ & & & & & \\
\hline 10 & & 20 & $1 / 5$ & 1 & & & & \\
\hline 11 & & 18 & $2 / 11.1$ & 2 & & & & \\
\hline 12 & & 10 & $7 / 70$ & & 6 & & & 1 \\
\hline 13 & $\mathrm{~F}$ & 37 & $13 / 35.1$ & 11 & & & & 2 \\
\hline 14 & G & 2 & $0 / 0$ & & & & & \\
\hline 15 & & 3 & $2 / 66.7$ & 1 & & & & 1 \\
\hline 16 & $\mathrm{H}$ & 12 & $2 / 16.7$ & & 2 & & & \\
\hline 17 & & 15 & $6 / 40$ & 3 & 1 & & & 2 \\
\hline 18 & & 11 & $0 / 0$ & & & & & \\
\hline 19 & I & 5 & $3 / 60$ & 1 & & 1 & 1 & \\
\hline 20 & J & 5 & $2 / 40$ & & & & 2 & \\
\hline Total & & 351 & $91 / 25.9$ & $57(62.6 \%)$ & $15(16.5 \%)$ & $3(3.3 \%)$ & $3(3.3 \%)$ & $13(14.3 \%)$ \\
\hline
\end{tabular}

*NAQ: Not sequenced due to low quality of DNA. 
with $C$. meleagridis. However, isolates characterized as $C$. baileyi showed two clusters one for CryBrFRChi 97/plus four isolates which clustered with GQ426096.1 and CryBrFRChi 101/plus nine isolates which clustered with AF093495.1 GenBank isolates. The isolates CryBrFRChi 70/71/108 showed higher evolutionary genetic distances (egd) $=0.006 / 100$ base pairs (bp) with $C$. bovis (AY741305.1), egd = 0.007/100bp for C. xiaoi (FJ896043.1), and egd $=0.014 / 100$ bp for $C$. ryanae .

The isolates CryBrFRChi 70/71/108 were then n-PCR tested for $h s p 70$ and actin genes. One sample (CryBrFRChi 70) did not have clear amplification in the actin gene and therefore was not analyzed; the other isolates were sequenced, and demonstrated low identities on BLAST for C. bovis in HSP70 gene (98\%, AY41306.1) and for actin gene (95\%, AY41307.1). Two isolates came from farm 20 (CryBrFRCh70, and CryBrFRCh71) and one from farm 19 (CryBrFRCh108), which were located in different cities. A phylogenetic tree is shown in Figure 2. Evolutionary genetic distances (egd)/100bp for C. bovis, C. ryanae, and C.xiaoi using the actin gene was $0.049,0.115$, and 0.042 and $0.022,0.131,0.027$ using $h s p 70$, respectively. Differences among isolates in regions of 18S rRNA n-PCR, hsp70 and actin genes are shown in Table 2. There were six, seven, and 43 differences in nucleotide sequences for $18 \mathrm{~S}$, $h s p 70$, and actin genes, respectively.

The nucleotide sequences were submitted at GenBank with accession numbers; MG209076-MG209080 and MG243623- MG243695 for 18S rRNA gene, and MG209081-MG209082 for actin gene, and MG209083-MG209085 for HSP70 gene.

The association of risk between the positivity from the $18 \mathrm{~S} r R N A$ n-PCR, and characteristics of the raising system, such as water source, population density, and presence of livestock, showed no significant differences in all variables analyzed ( $p>0.06)$.

\section{Discussion}

To the best of the author's knowledge, this study shows, for the first time, the molecular prevalence and characterization of Cryptosporidium spp. in fecal samples from free-range chickens. Here,
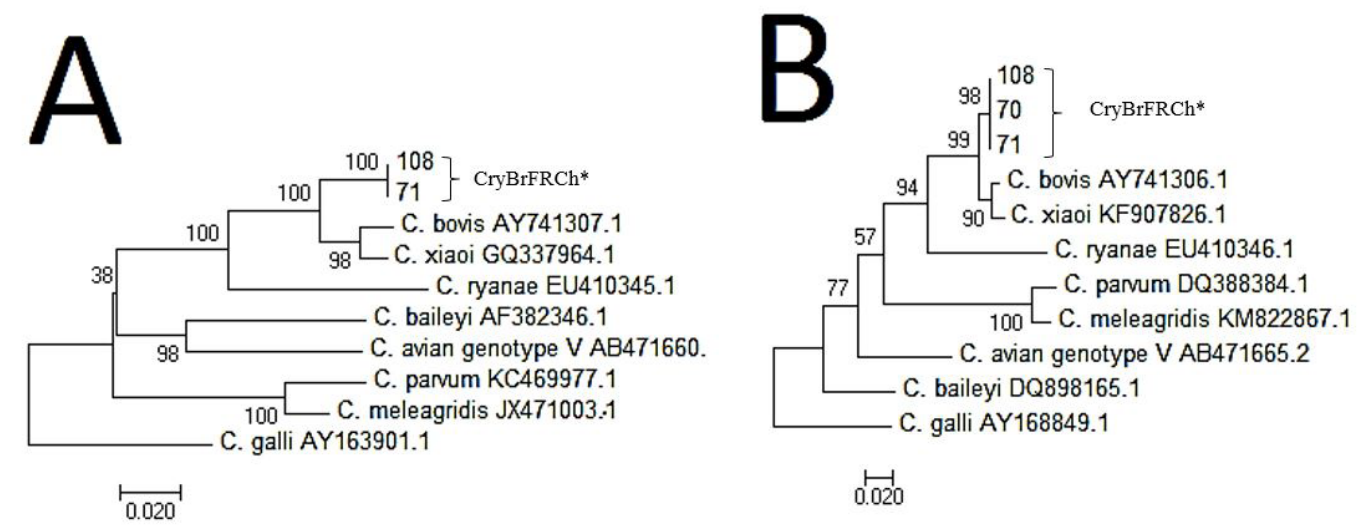

Figure 2. Phylogenetic relationships between Cryptosporidium spp. found in this study by partial DNA sequences of actin (A), and HSP70 (B) loci and selected Cryptosporidium spp. from GenBank inferred by model Kimura 2-parameter. The percentage of replicate trees in which the associated taxa clustered together in the bootstrap test (1000 replicates) is shown next to the branches. Cryptosporidium galli was used as outgroup. Isolates obtained in the present study were marked as CryBrFRCh\# (Cryptosporidium Brazil Free Range Chickens and the number of respective sample). *New genotype (Cryptosporidium genotype BrPR1).

Table 2. Nucleotide substitutions at $18 \mathrm{~S}$ rRNA, HSP70, and actin genes from isolates of present study (CryBrFRChi 70/71/108).

\begin{tabular}{|c|c|c|c|c|c|c|c|c|c|c|c|c|c|c|c|c|c|c|c|c|c|c|}
\hline $18 S$ rRNA & 14 & 395 & 396 & 426 & 442 & 570 & & & & & & & & & & & & & & & & \\
\hline CryBrFRChi70 / 71 / 108 & $\mathrm{G}$ & $\mathrm{T}$ & A & $\mathrm{C}$ & G & G & & & & & & & & & & & & & & & & \\
\hline C. bovis AY741305.1 & A & $\mathrm{C}$ & . & $\mathrm{T}$ & A & . & & & & & & & & & & & & & & & & \\
\hline C. xiaoi FJ896043.1 & A & . & $\mathrm{T}$ & $\mathrm{T}$ & A & A & & & & & & & & & & & & & & & & \\
\hline HSP70 & 3 & 15 & 33 & 63 & 114 & 135 & 213 & & & & & & & & & & & & & & & \\
\hline CryBrFRChi70, $71 / 108$ & $\mathrm{C}$ & $\mathrm{T}$ & G & $\mathrm{T}$ & G & $\mathrm{C}$ & $\mathrm{T}$ & & & & & & & & & & & & & & & \\
\hline C. bovis AY741306.1 & $\mathrm{T}$ & . & . & $\mathrm{C}$ & A & $\mathrm{T}$ & $\mathrm{C}$ & & & & & & & & & & & & & & & \\
\hline C. xiaoi FJ896041.1 & $\mathrm{T}$ & $\mathrm{C}$ & $\mathrm{A}$ & $\mathrm{C}$ & . & $\mathrm{T}$ & $\mathrm{C}$ & & & & & & & & & & & & & & & \\
\hline Actin & 36 & 117 & 129 & 147 & 150 & 153 & 198 & 216 & 219 & 249 & 279 & 303 & 321 & 366 & 369 & 372 & 387 & 393 & 414 & 438 & 447 & 453 \\
\hline CryBrFRChi71 / 108 & A & A & $\mathrm{T}$ & A & A & $\mathrm{T}$ & G & $\mathrm{C}$ & $\mathrm{C}$ & A & G & $\mathrm{T}$ & $\mathrm{T}$ & A & G & $\mathrm{C}$ & $\mathrm{T}$ & $\mathrm{T}$ & G & G & $\mathrm{C}$ & G \\
\hline C. bovis AY741307.1 & G & G & G & G & G & A & A & $\mathrm{T}$ & $\mathrm{T}$ & $\mathrm{T}$ & A & A & $\mathrm{C}$ & G & . & $\mathrm{T}$ & $\mathrm{C}$ & A & A & A & $\mathrm{T}$ & A \\
\hline \multirow[t]{2}{*}{ C. xiaoi GQ337964.1 } & . & . & G & G & . & $\mathrm{A}$ & $\mathrm{A}$ & $\mathrm{T}$ & $\mathrm{T}$ & G & A & . & $\mathrm{C}$ & G & $\mathrm{A}$ & $\mathrm{T}$ & $\mathrm{C}$ & $\mathrm{A}$ & $\mathrm{A}$ & . & $\mathrm{T}$ & . \\
\hline & 483 & 501 & 507 & 540 & 555 & 558 & 576 & 585 & 618 & 624 & 633 & 639 & 666 & 687 & 714 & 723 & 732 & 735 & 744 & 759 & 786 & \\
\hline CryBrFRChi71 / 108 & $\mathrm{~T}$ & $\mathrm{C}$ & G & G & $\mathrm{C}$ & G & G & A & A & A & A & $\mathrm{C}$ & $\mathrm{C}$ & A & $\mathrm{T}$ & $\mathrm{T}$ & A & A & A & $\mathrm{T}$ & $\mathrm{C}$ & \\
\hline C. bovis AY741307.1 & . & . & A & A & $\mathrm{T}$ & A & A & G & G & G & . & $\mathrm{T}$ & . & G & $\mathrm{C}$ & $\mathrm{C}$ & G & $\mathrm{T}$ & G & $\mathrm{C}$ & $\mathrm{T}$ & \\
\hline C. xiaoi GQ337964.1 & $\mathrm{C}$ & $\mathrm{T}$ & . & $\mathrm{A}$ & $\mathrm{T}$ & A & A & G & G & . & G & $\mathrm{T}$ & $\mathrm{T}$ & . & $\mathrm{C}$ & . & G & $\mathrm{T}$ & G & $\mathrm{C}$ & $\mathrm{T}$ & \\
\hline
\end{tabular}


the $18 \mathrm{~S}$ rRNA n-PCR reactions were positive for Cryptosporidium spp. in $91(25.9 \%)$ of 351 fecal samples

There are few reports of Cryptosporidium molecular characterization from chickens in Brazil (HUBER et al., 2007; NAKAMURA et al., 2009) and worldwide (HSU et al., 2008; NG et al., 2006; SILVERLÅS et al., 2012; WANG et al., 2014), however, none of the previously studies reported studies worked with free-range chickens. In Brazil, Huber et al. (2007) and Nakamura et al. (2009) worked with chickens from indoor public markets and chickens under captivity, respectively. The authors from other regions of world isolated Cryptosporidium spp. from commercial poultry farms, layer chickens, and pet shops.

In the present study, all positive samples tested at $18 \mathrm{~S}$ rRNA n-PCR were submitted to sequencing, and 62.6\%, 16.4\%, 3.2\%, and $3.2 \%$ were detected as C. meleagridis, C. baileyi, C. parvum, and a new genotype named $C$. genotype BrPR1, respectively. Similar results were observed by Baroudi et al. (2013), who studied 90 broiler chickens from 23 farms in Algeria; which found by $18 \mathrm{~S}$ rRNA gene $28.9 \%$ of C. meleagridis, and $5.5 \%$ of C. baileyi. Conversely, $C$. baileyi had been previously reported as the most common Cryptosporidium species in chickens (FAYER, 2010). There are few reports in Brazil on the occurrence of $C$. baileyi infecting domestic chickens (CARDOZO et al., 2005; MEIRELES \& FIGUEIREDO, 1992). Herein, we observed two clusters in $18 \mathrm{~S}$ rRNA gene phylogenetic tree from $C$. baileyi, this can be explained by genetic diversity observed in sequences of GenBank.

In a previous study by Nakamura et al. (2009), C. meleagridis was found in one sample of a domestic chicken in Brazil. Previous studies performed outside Brazil affirm that infections by C. baileyi, C. galli and other parasite genotypes are present in several avian cases. While the number of reports of infection by $C$. meleagridis was low (SRÉTER \& VARGA, 2000; WANG et al., 2014), $\mathrm{Ng}$ et al. (2006) did not find this species in 430 avian fecal samples, and described that $C$. meleagridis infection has low prevalence in avian hosts. This finding is the opposite what we observed in our results. C. meleagridis has a wide host range, and it is the third most prevalent species infecting humans (CAMA et al., 2003; ELWIN et al., 2012; GATEI et al., 2003; GUYOT et al., 2001; LEONI et al., 2006; PEDRAZA-DÍAZ et al., 2000; XIAO, 2010). This species is considered an important human pathogen, accounting for several reports of human infection (DARABUS, 1997; DARABUS \& OLARIU, 2003; SRÉTER \& VARGA, 2000; XIAO \& FENG, 2008). A study in England found C. meleagridis in $0.9 \%$ of 2,414 human cases (LEONI et al., 2006). Sequence analysis of the $18 \mathrm{~S}$ rRNA gene and $h s p 70$ loci has been used to provide evidence of zoonotic transmission of $C$. meleagridis from chickens to humans on a Swedish farm (SILVERLÅS et al., 2012).

C. parvum was detected in three animals from two farms; therefore, animals could be acting as an environment spread host, considering that viable oocysts of $C$. parvum can pass undamaged through the digestive system of several avian hosts (GRACZYK et al., 1996, 1997). Oocysts of $C$. parvum were detected in feces of wild Canada geese (Branta canadensis) (GRACZYK et al., 1998), and it was demonstrated experimentally to cause a weak tracheal infection in 1- and 7-day-old chickens (LINDSAY et al., 1987). However, molecular detection of C. parvum in feces of chickens is uncommon (BAROUDI et al., 2013; HUBER et al., 2007; NAKAMURA et al., 2009; NG et al., 2006)

In the present work, sequencing of $18 \mathrm{~S}$ rRNA amplicons allowed the identification of a new Cryptosporidium genotype in three samples, and consequently we performed actin and hsp70 n-PCR and sequencing of the identified isolates. The results showed identities of these genes with C. bovis between $95 \%$ to $98 \%$. Thus, because of such genetic distance with C. bovis, C. ryanae, and $C$. xiaoi we named this new genotype as Cryptosporidium genotype PR1.

There were no significant differences in all variables studied here that could be associated to cryptosporidiosis. It is known that water can act as a transmission route of oocysts to birds and acts as a major source of oocysts and human outbreaks in developed countries, including North America, the United Kingdom, and Japan (FAYER, 2004). In the present work, although no significance was observed, the farms that were provided with deep water showed a reduction in positive animals $(20 \%)$ when compared with surface water $(30 \%)$.

\section{Conclusion}

Cryptosporidium, including zoonotic species, exists at a high prevalence in free-range chickens. A high prevalence of farms positive for Cryptosporidium, mainly $C$. meleagridis, shows us the importance of the chicken as an environmental indicator for this zoonotic protozoa. Other studies must be performed to better elucidate the role of chickens in the dissemination of Cryptosporidium species that infect cattle. We described a new genotype of Cryptosporidum which was named $C$. genotype BrPR1.

\section{References}

Baroudi D, Khelef D, Goucem R, Adjou KT, Adamu H, Zhang H, et al. Common occurrence of zoonotic pathogen Cryptosporidium meleagridis in broiler chickens and turkeys in Algeria. Vet Parasitol 2013; 196(3-4): 334340. PMid:23498647. http://dx.doi.org/10.1016/j.vetpar.2013.02.022.

Cama VA, Bern C, Sulaiman IM, Gilman RH, Ticona E, Vivar A, et al Cryptosporidium species and genotypes in HIV-positive patients in Lima, Peru. J Eukaryot Microbiol 2003;50(Suppl): 531-533. PMid:14736153. http://dx.doi.org/10.1111/j.1550-7408.2003.tb00620.x.

Cama VA, Ross JM, Crawford S, Kawai V, Chavez-Valdez R, Vargas $\mathrm{D}$, et al. Differences in clinical manifestations among Cryptosporidium species and subtypes in HIV-infected persons. J Infect Dis 2007; 196(5): 684-691.

Cardozo SV, Teixeira-Filho WL, Lopes CWG. Transmissão experimental de Cryptosporidium baileyi (Apicomplexa: Cryptosporidiidae) isolado de frango de corte à codorna japonesa (Coturnix japonica). Rev Bras Parasitol Vet 2005; 14(3): 119-124. PMid:16229756.

Chappell CL, Okhuysen PC, Langer-Curry RC, Akiyoshi DE, Widmer G, Tzipori S. Cryptosporidium meleagridis: infectivity in healthy adult volunteers. Am J Trop Med Hyg 2011; 85(2): 238-242. PMid:21813841. http://dx.doi.org/10.4269/ajtmh.2011.10-0664.

Chappell CL, Okhuysen PC, Langer-Curry RC, Lupo PJ, Widmer G, Tzipori S. Cryptosporidium muris: infectivity and illness in healthy adult 
volunteers. Am J Trop Med Hyg 2015; 92(1): 50-55. PMid:25311695. http://dx.doi.org/10.4269/ajtmh.14-0525.

Current WL, Upton SJ, Haynes TB. The life cycle of Cryptosporidium baileyi n. sp. (Apicomplexa, Cryptosporidiidae) infecting chickens. J Protozool 1986; 33(2): 289-296. PMid:3735157. http://dx.doi. org/10.1111/j.1550-7408.1986.tb05608.x.

Darabus G. Experimental studies of inter and intraspecif transmission of Cryptosporidium parvum and C. meleagridis. Rev Rom Med Vet 1997; 7(2): 155-160.

Darabus G, Olariu R. The homologous and interspecies transmission of Cryptosporidium parvum and Cryptosporidium meleagridis. Pol J Vet Sci 2003; 6(3): 225-228. PMid:14510055.

Dean A, Arner T, Sunki G, Friedman R, Lantinga M, Sangam S, et al. EpiInfo a database and statistics program for public health professionals. Clifton: Epi Info ${ }^{\mathrm{TM}} ; 2011$.

Elwin K, Hadfield SJ, Robinson G, Chalmers RM. The epidemiology of sporadic human infections with unusual cryptosporidia detected during routine typing in England and Wales, 2000-2008. Epidemiol Infect 2012; 140(4): 673-683. PMid:21733255. http://dx.doi.org/10.1017/ S0950268811000860.

Fayer R. Cryptosporidium: a water-borne zoonotic parasite. Vet Parasitol 2004; 126(1-2): 37-56. PMid:15567578. http://dx.doi.org/10.1016/j. vetpar.2004.09.004.

Fayer R. Taxonomy and species delimitation in Cryptosporidium. Exp Parasitol 2010; 124(1): 90-97. PMid:19303009. http://dx.doi.org/10.1016/j. exppara.2009.03.005.

Gatei W, Greensill J, Ashford RW, Cuevas LE, Parry CM, Cunliffe NA, et al. Molecular analysis of the $18 \mathrm{~S}$ rRNA gene of Cryptosporidium parasites from patients with or without human immunodeficiency virus infections living in Kenya, Malawi, Brazil, the United Kingdom, and Vietnam. J Clin Microbiol 2003; 41(4): 1458-1462. PMid:12682130. http://dx.doi.org/10.1128/JCM.41.4.1458-1462.2003.

Graczyk T, Fayer R, Trout J, Lewis E, Farley CA, Sulaiman I, et al. Giardia sp. cysts and infectious Cryptosporidium parvum oocysts in the feces of migratory Canada geese (Branta canadensis). Appl Environ Microbiol 1998; 64(7): 2736-2738. PMid:9647860.

Graczyk TK, Cranfield MR, Fayer R, Anderson MS. Viability and infectivity of Cryptosporidium parvum oocysts are retained upon intestinal passage through a refractory avian host. Appl Environ Microbiol 1996; 62(9): 3234-3237. PMid:8795213.

Graczyk TK, Cranfield MR, Fayer R, Trout J, Goodale HJ. Infectivity of Cryptosporidium parvum oocysts is retained upon intestinal passage through a migratory water-fowl species (Canada goose, Branta canadensis). Trop Med Int Health 1997; 2(4): 341-347. PMid:9171842. http://dx.doi. org/10.1111/j.1365-3156.1997.tb00149.x.

Griffiths JK. Human cryptosporidiosis: epidemiology, transmission, clinical disease, treatment, and diagnosis. Adv Parasitol 1998; 40: 37-85. PMid:9554070. http://dx.doi.org/10.1016/S0065-308X(08)60117-7.

Guyot K, Follet-Dumoulin A, Lelievre E, Sarfati C, Rabodonirina M, Nevez G, et al. Molecular characterization of Cryptosporidium isolates obtained from humans in France. J Clin Microbiol 2001; 39(10): 34723480. PMid:11574558. http://dx.doi.org/10.1128/JCM.39.10.34723480.2001

Hall TA. BioEdit: a user-friendly biological sequence alignment editor and analysis program for Windows 95/98/NT. Nucleic Acids Symp Ser 1999; 41: 95-98
Hsu BM, Wun HY, Hsu CLL. Detection and species identification of Cryptosporidium from Taiwan feeding animals. J Parasitol 2008; 94(1): 252-256. PMid:18372647. http://dx.doi.org/10.1645/GE-1135.1.

Huber F, da Silva S, Bomfim TCB, Teixeira KRS, Bello AR. Genotypic characterization and phylogenetic analysis of Cryptosporidium sp. from domestic animals in Brazil. Vet Parasitol 2007; 150(1-2): 65-74. PMid:17905514. http://dx.doi.org/10.1016/j.vetpar.2007.08.018.

Leoni F, Amar C, Nichols G, Pedraza-Díaz S, McLauchlin J. Genetic analysis of Cryptosporidium from 2414 humans with diarrhoea in England between 1985 and 2000. J Med Microbiol 2006; 55(Pt 6 ): 703-707. PMid:16687587. http://dx.doi.org/10.1099/jmm.0.46251-0.

Lindsay DS, Blagburn BL, Ernest JA. Experimental Cryptosporidium parvum infections in chickens. J Parasitol 1987; 73(1): 242-244. PMid:3572661. http://dx.doi.org/10.2307/3282381.

MacKenzie WR, Hoxie NJ, Proctor MEM, Gradus MS, Blair KA, Peterson DE, et al. A massive outbreak in milwaukee of Cryptosporidium infection transmitted through the public water supply. $N$ Engl J Med 1994; 331(3): 161-167. PMid:7818640. http://dx.doi.org/10.1056/ NEJM199407213310304.

Meireles MV, Figueiredo PC. Isolamento e identificação do Cryptosporidium baileyi current et alii, 1986 (Apicomplexa: Cryptosporidiidae) em frangos de corte. Rev Bras Parasitol Vet 1992; 1(2): 125-130.

Nakamura AA, Simóes DC, Antunes RG, Silva DC, Meireles MV. Molecular characterization of Cryptosporidium spp. from fecal samples of birds kept in captivity in Brazil. Vet Parasitol 2009; 166(1-2): 47-51. PMid:19683397. http://dx.doi.org/10.1016/j.vetpar.2009.07.033.

$\mathrm{Ng}$ J, Pavlasek I, Ryan U. Identification of novel Cryptosporidium genotypes from avian hosts. Appl Environ Microbiol 2006; 72(12): 7548-7553. PMid:17028234. http://dx.doi.org/10.1128/AEM.01352-06.

Pavlásek I. Findings of cryptosporidia in the stomach of hens and of exotic and wild birds. Veterinarstvi 2001; 51: 103-108.

Pedraza-Díaz S, Amar C, McLauchlin J. The identification and characterisation of an unusual genotype of Cryptosporidium from human faeces as Cryptosporidium meleagridis. FEMS Microbiol Lett 2000; 189(2): 189-194. PMid:10930736. http://dx.doi.org/10.1016/ S0378-1097(00)00278-0.

Ryan U, Hijjawi N. New developments in Cryptosporidium research. Int J Parasitol 2015; 45(6): 367-373. PMid:25769247. http://dx.doi. org/10.1016/j.ijpara.2015.01.009.

Shields JM, Gleim ER, Beach MJ. Prevalence of Cryptosporidium spp. and Giardia intestinalis in Swimming Pools, Atlanta, Georgia. Emerg Infect Dis 2008; 14(6): 948-950. PMid:18507911. http://dx.doi.org/10.3201/ eid1406.071495.

Silverlås C, Mattsson JG, Insulander M, Lebbad M. Zoonotic transmission of Cryptosporidium meleagridis on an organic Swedish farm. Int J Parasitol 2012; 42(11): 963-967. PMid:23022616. http://dx.doi.org/10.1016/j. ijpara.2012.08.008.

Slavin D. Cryptosporidium meleagridis (sp. nov.). J Comp Pathol 1955; 65(3): 262-266. PMid:13242675. http://dx.doi.org/10.1016/S03681742(55)80025-2.

Smith HV, Cacciò SM, Cook N, Nichols RB, Tait A. Cryptosporidium and Giardia as foodborne zoonoses. Vet Parasitol 2007; 149(1-2): 2940. PMid:17728067. http://dx.doi.org/10.1016/j.vetpar.2007.07.015. 
Sréter T, Varga I. Cryptosporidiosis in birds--a review. Vet Parasitol 2000; 87(4): 261-279. PMid:10669097. http://dx.doi.org/10.1016/ S0304-4017(99)00178-8.

Sulaiman IM, Lal AA, Xiao L. Molecular phylogeny and evolutionary relationships of Cryptosporidium parasites at the actin locus. J Parasitol 2002; 88(2): 388-394. PMid:12054017. http://dx.doi.org/10.1645/00223395(2002)088[0388:MPAERO]2.0.CO;2.

Sulaiman IM, Morgan UM, Thompson RCA, Lal AA, Xiao L. Phylogenetic relationships of Cryptosporidium parasites based on the 70-Kilodalton heat shock protein (HSP70) gene. Appl Environ Microbiol 2000; 66(6): 2385-2391. PMid:10831415. http://dx.doi.org/10.1128/AEM.66.6.23852391.2000 .

Tangermann RH, Gordon S, Wiesner P, Kreckman L. An outbreak of cryptosporidiosis in a day-care center in Georgia. Am J Epidemiol 1991; 133(5): 471-476. PMid:2000857. http://dx.doi.org/10.1093/ oxfordjournals.aje.a115914.

Thamsborg SM, Roepstorff A, Larsen MM. Integrated and biological control of parasites in organic and conventional production systems. Vet Parasitol 1999; 84(3-4): 169-186. PMid:10456414. http://dx.doi. org/10.1016/S0304-4017(99)00035-7.
Wang KH, Shi SR, Dou TC, Sun HJ. Effect of a free-range raising system on growth performance, carcass yield, and meat quality of slow-growing chicken. Poult Sci 2009; 88(10): 2219-2223. PMid:19762879. http:// dx.doi.org/10.3382/ps.2008-00423.

Wang L, Xue X, Li J, Zhou Q, Yu Y, Du A. Cryptosporidiosis in broiler chickens in Zhejiang Province, China: molecular characterization of oocysts detected in fecal samples. Parasite 2014; 21: 36. PMid:25075975. http://dx.doi.org/10.1051/parasite/2014035.

Xiao L, Feng Y. Zoonotic cryptosporidiosis. FEMS Immunol Med Microbiol 2008; 52(3): 309-323. PMid:18205803. http://dx.doi.org/10.1111/j.1574695X.2008.00377.x.

Xiao L, Morgan UMU, Limor J, Escalante A, Arrowood M, Shulaw W, et al. Genetic diversity within Cryptosporidium parvum and related Cryptosporidium species. Appl Environ Microbiol 1999; 65(8): 3386-3391. PMid:10427023.

Xiao L. Molecular epidemiology of cryptosporidiosis: an update. Exp Parasitol2010; 124(1): 80-89. PMid:19358845. http://dx.doi.org/10.1016/j. exppara.2009.03.018. 